\title{
Pengembangan Usaha dan Rebranding Produk Yuki Brownies
}

\author{
${ }^{1 *}$ Ni Wayan Deriani, ${ }^{2}$ Ni Made Astiti, ${ }^{3}$ I Komang Try Adi Stanaya \\ Institut Teknologi dan Bisnis STIKOM Bali \\ deriani@stikom-bali.ac.id, astiti@stikom-bali.ac.id,tryadi@stikom-bali.ac.id
}

\begin{abstract}
ABSTRAK
Yuki brownies memiliki kendala terkait sarana dan prasarana produksi yaitu mesin panggang yang dimiliki hanya satu buah saja, varian produk yang dimiliki hanya dua yaitu cake pisang dan brownies, serta di dalam manajemen usahanya juga belum dilakukan dengan baik. Pengabdian masyarakat terdiri atas beberapa kegiatan, yaitu pemberian satu buah alat panggang/mesin oven, melakukan pengembangan varian produk yuki brownies dengan membuat varian baru dari yuki brownies, dan yang terakhir adalah melakukan rebranding product dari yuki brownies. Metode penelitian yang dilakukan adalah dengan melakukan sosialisasi dan pendampingan pembuatan varian baru dari produk yuki brownies, melakukan rebranding kemasan, logo, desain pembungkus serta sosialisasi manajemen pengemabangan usaha yuki brownies. Output pengabdian berupa dihasilkannya desain kemasan, varian jenis baru dari produk yuki brownies, dan adanya pengetahuan yang dimiliki oleh mitra dalam hal pengembangan usaha yuki brownies, hasil evaluasi efektivitas pelaksanaan pengabdian dapat dilihat dari data penjualan produk mitra yang diukur dari bulan Februari - Mei 2020 sebesar Rp 9.200.000 di mana dari penjualan tersebut terdiri $13 \%$ di bulan pebruari, $19 \%$ di bulan maret, $25 \%$ di bulan april dan $43 \%$ di bulan mei 2020 , hal tersebut menunjukkan peningkatan setiap bulannya. Desain baru terutama untuk kemasan dan tas belanja telah mengurangi penggunaan plastik hingga $75 \%$, dan hal ini berdampak baik bagi lingkungan. Bantuan satu buah mesin panggang/oven telah memenuhi jumlah pesanan hingga 100\%. Dapat disimpulkan bahwa jumlah produksi bisa meningkat $50 \%$.
\end{abstract}

Kata kunci : Rebranding, Kemasan, Desain Produk

\begin{abstract}
Yuki brownies have problems related to production facilities and infrastructure, namely the roasting machine that has only one fruit, only 2 product variants, namely banana cake and brownies, and in business management it has not been done properly, to deal with partner problems, in service activities Several activities were carried out, namely the provision of a roasting appliance / oven machine, developing a variant of the yuki brownie product by making a new variant of yuki brownie and the last is by rebranding the product from yuki brownie. The research method used is to conduct socialization and assistance in making new variants of yuki brownie products, rebranding the packaging, logo, design of the packaging and socializing the management of yuki brownie business development. Service output in the form of packaging designs, new types of yuki brownie product variants, and the knowledge that partners have in terms of developing a yuki brownie business, the results of evaluating the effectiveness of service implementation can be seen from partner product sales data measured from February - May 2020 of IDR 9,200,000 of which sales consisted of 13\% in February, 19\% in March, 25\% in April and 43\% in May 2020, this shows an increase every month. The new design, especially for packaging and shopping bags, reduces the use of plastic by up to $75 \%$, and this is good for the environment. And with the help of 1 roasting
\end{abstract}


machine /oven can fulfill the order number up to $100 \%$. It can be concluded that the amount of production could increase by $50 \%$.

Key words: Rebranding, Packaging, Product Design

\section{PENDAHULUAN}

MitraYuki brownies merupakan usaha rumahan yang memproduksi kue seperti brownies sebagai produk unggulannya, kegiatan produksi dikerjakan sendiri oleh mitra namun kadang dibantu oleh keluarga. Yuki brownies menerima pesanan melalui media online yaitu facebook dan instagram dan WhatsApp, namun pemanfaatannya kurang maksimal dan sering terjadi kesalahan pemesanan seperti pesanan ganda, terlewatnya order karena tidak terbaca. Selain itu juga, Yuki brownies bekerjasama dengan reseller untuk meningkatkan omset penjualannya. Usaha yuki brownies ini dimulai sejak tahun 2017 menyadari bahwa banyaknya saingan dan maraknya produk sejenis dipasar merupakan faktor yang harus dijadikan semangat untuk terus berinovasi sehingga bisa bersaing dipasar.

Mitra yuki brownies memiliki kendala dalam keterbatasan dalam pengembangan usaha antara lain minimnya sarana dan prasarana seperti mesin oven, tidak mempunyai logo atau brand untuk produk yuki brownies, terbatasnya varian produk yang dimiliki serta masih minimnya jumlah pelanggan yang ada

Saran yang diberikan adalah rebranding produk yuku brownies, adanya penambahan varian produk, adanya sosialisasi pengembangan usaha dari yuki brownies. Adapun analisis situasi dari mitra yuki brownies dapat dilihat pada tabel 1 berikut ini.

Tabel 1. Analisis Situasi

\begin{tabular}{|l|l|l|l|}
\hline No & Bidang & Permasalahan & Solusi \\
\hline 1 & $\begin{array}{l}\text { Sarana } \\
\text { dan }\end{array}$ & $\begin{array}{l}\text { Mitra hanya } \\
\text { memiliki 1 }\end{array}$ & $\begin{array}{l}\text { Memberi } \\
\text { kan }\end{array}$ \\
\hline
\end{tabular}

\begin{tabular}{|c|c|c|c|}
\hline & prasarana & $\begin{array}{l}\text { mesin } \\
\text { panggang }\end{array}$ & $\begin{array}{l}\text { bantuan } \\
\text { hibah } \\
\text { alat } \\
\text { berupa } \\
\text { mesin } \\
\text { panggang }\end{array}$ \\
\hline 2 & $\begin{array}{l}\text { Company } \\
\text { profile }\end{array}$ & $\begin{array}{l}\text { Pengembanga } \\
\mathrm{n} \text { dan } \\
\text { branding yuki } \\
\text { brownies }\end{array}$ & $\begin{array}{l}\text { Melakuk } \\
\text { an } \\
\text { rebrandin } \\
\text { g yuki } \\
\text { brownies }\end{array}$ \\
\hline 3 & $\begin{array}{l}\text { Manajem } \\
\text { en Usaha }\end{array}$ & $\begin{array}{l}\text { Pengembanga } \\
\text { n varian } \\
\text { produk \& } \\
\text { pengembanga } \\
\text { n usaha }\end{array}$ & $\begin{array}{l}\text { Sosialisa } \\
\text { si } \\
\text { pengemb } \\
\text { angan } \\
\text { produk } \\
\text { dan } \\
\text { usaha }\end{array}$ \\
\hline
\end{tabular}

\section{RUMUSAN MASALAH}

Bagaimanakah melakukan rebranding dan pengembangan usaha yuki brownies sehingga dapat meningkatkan penjualan produk dari yuki brownies?

\section{METODE}

1. Melukakan rebranding terhadap yuki brownies dengan melakukan perubahan pada logo dan desain kemasan dari yuki brownies. Dapat dilakukan dengan pendampingan pembuatan desain logo yang dapat disesuaikan dengan ciri khusus dari yuki brownies sehingga memiliki self identity yang membedakan produk yuki brownies dengan pesaingnya. Pentingnya sebuah brand terutama karena brand dapat mempengaruhi perilaku pembelian konsumen, membantu produsen atau penjual mendapatkan harga lebih tinggi atas produk yang dihasilkannya mengingat konsumen yang brand-minded akan bersedia membayar dengan harga 
premium terhadap suatu produk jika berasal dari brand tertentu. [1]

2. Melakukan sosialisasi dan pendampingan kepada mitra dalam hal pengembangan varian produk baru dan menejemen usaha untuk meningkatkan jangkauan pasar dari yuki brownies.

\section{PEMBAHASAN}

Tahapan kegiatan adalah sebagai berikut:

\section{a. Rebranding dan desain kemasan dari yuki rownies.}

Branding dalam komunikasi pemasaran brand atau yang dikenal dengan brand bukan sekedar nama dan logo. Menurut Kotler Philip (2000) brand adalah sebuah nama, istilah, tanda, symbol, rancangan atau kombinasi semua unsur yang digunakan untuk mengenali produk atau jasa dari seseorang atau sebuah kelompok penjual dari pesaingnya. [1]

Perusahaan yang telah memiliki brand cenderung mempunyai inovasiinovasi yang baru terkait perancangan produk ataupun terkait dengan lingkungan internal perusahaan. Inovasi baru tersebut akan memberi dampak positif secara visual, dengan membuat kebaharuan melalui rebranding perusahaan.

Adapun rebranding yang dilakukan berupa redesain kemasan, kantong belanja, logo, tas belanja dan branding lainnya dari yuki brownies.

$$
\text { Meningkatnya masalah }
$$

lingkungan telah meningkat minat konsumen pada produk hijau dan jasa. Eco-label dan produk ramah lingkungan sedang semakin dipromosikan oleh perusahaan. Beberapa peneliti telah mempelajari pengaruh strategi pemasaran dan komunikasi hijau pada perilaku pembelian konsumen. Pickett-Baker dan Ozaki (2008) mempelajari efek dari teknik pemasaran dan branding dalam membangun persepsi positif dari pemasaran hijau di kalangan konsumen. [2].

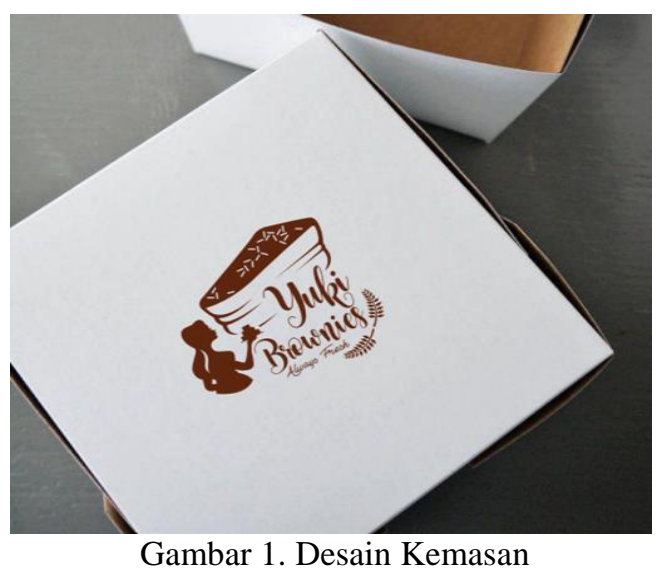

Pada gambar 1 diatas merupakan desain kemasan berupa box makanan untuk pembungkus kue yuki brownies, bahannya terbuat dari kertas yang bertujuan untu mengurangi limbah sampah plastik.

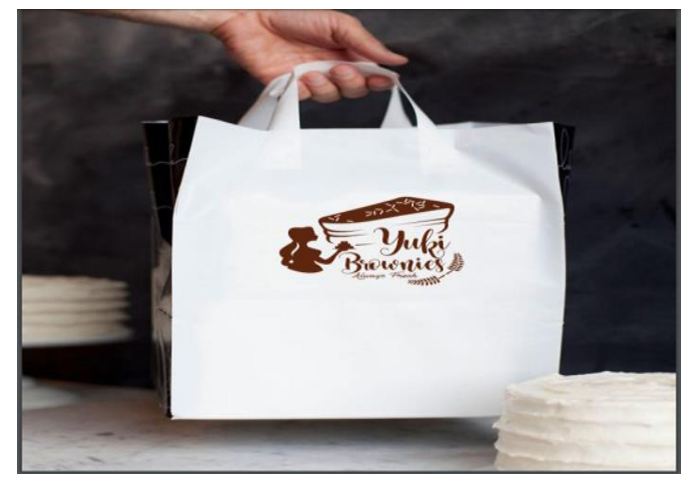

Gambar 2. Desain Kantong Belanja

Pada gambar 2 diatas adalah desain kemasan tas beanja, sama halnya dengan box makanan dari yuki brownies, kantong belanja didesain menggunakan bahan kertas sehingga lebih ramah lingkunga. Selain ramah lingkungan, kantong pembungkus ini memiliki tujuan marketing yaitu sebagai self identity yang dimiliki oleh yuki brownies.

\section{Menurut Simmons} pentingnya self identity juga berdampak pada kesan perusahaan yang memiliki indentitas unik, menarik, dan mudah diingat, serta membuat perusahaan mendapatkan ceruk pasar yang semakin 
besar dibandingkan produk atau jasa sejenis lainnya. [3]

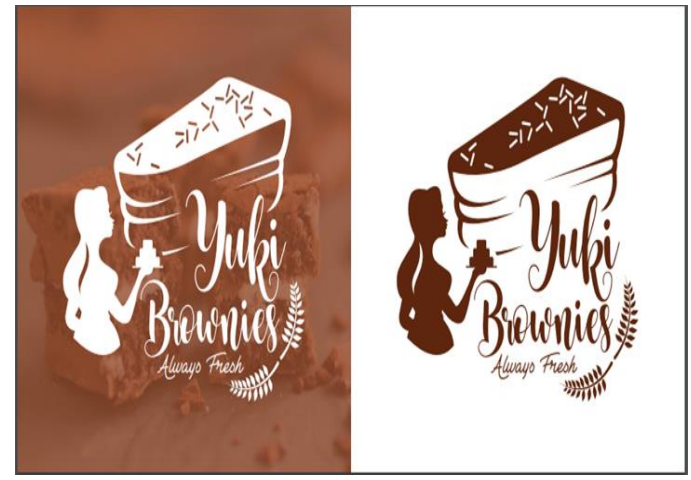

Gambar 3. Desain logo

Selanjutnya pada gambar 3, merupakan desain logo untuk yuki brownies, desain logo ini merupakan cerminan dari yuki brownies dengan pilosofi yang terkandung dibalik logo dari yuki brownies. Logo yuki brownies ini memiliki pilosofi dari namanya yaitu "yuki" merupakan nama panggilan dari pemilik yuki brownies. Pada logo yuki brownies juga terdapat elemen logo seperti tampilan potongan sebuah kue, yang dalam hal ini menekankan pada potongan brownies, yang memberi kesan identitas, dan mudah diingat pada logo yuki brownies.

Pembuatan logo yuki brownies ini menggunakan konsep brand redesigning, dimana tujuan dari konsep brand redesigning yaitu untuk membawa keluar semua elemen dari organisasi, yang mana tampak dari manifestasi posisi yang diinginkan oleh perusahaan. [4]

Dalam suatu perusahaan, logo sangat berperan penting untuk mewakili ciri dari pada produk yang diproduksi, sehingga dapat membantu dalam hal memperkenalkan usaha atau bisnis kepada konsumen. Sebuah usaha kecil yang sukses memerlukan logo yang tepat dan memerlukan pengakuan yang didapat dari sebuah logo bisnis yang baik. [5]

Keberadaan logo sangat erat kaitannya dengan citra perusahaan. Biasanya orang-orang mampu menilai seperti apa kualitas atau keprofesionalan sebuah perusahaan hanya dengan melihat logo dari perusahaan tersebut. [6]

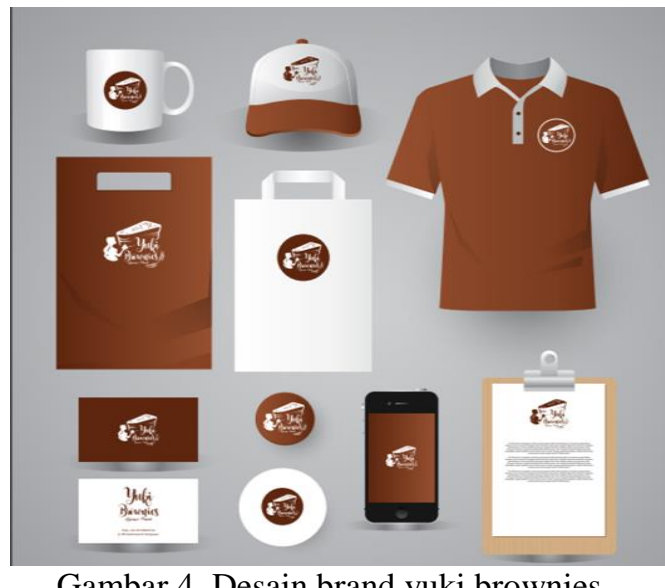

Gambar 4. Desain brand yuki brownies

Selain mendesain kemasan, kantong benja dan logo dari yuki brownies, pada gambar 4 diatas juga telah didesain branding yuki broenies yang lainnya seperti mug, topi, seragam, kartu nama, desain aplikasi dan branding lainnya.

\section{b. Pengembangan Varian Produk dan Varian Rasa}

Dikembangkannya varian baru dari produk yuki brownies untuk menambah varian produk yuki brownies, produk yang dikembangkan jenis cotton cake, dimana ssebelunya yuki brownies hanya menghasikan brownies saja. Varian baru dari produk yuki brownies terlihat pada gambar 5 berikut ini.

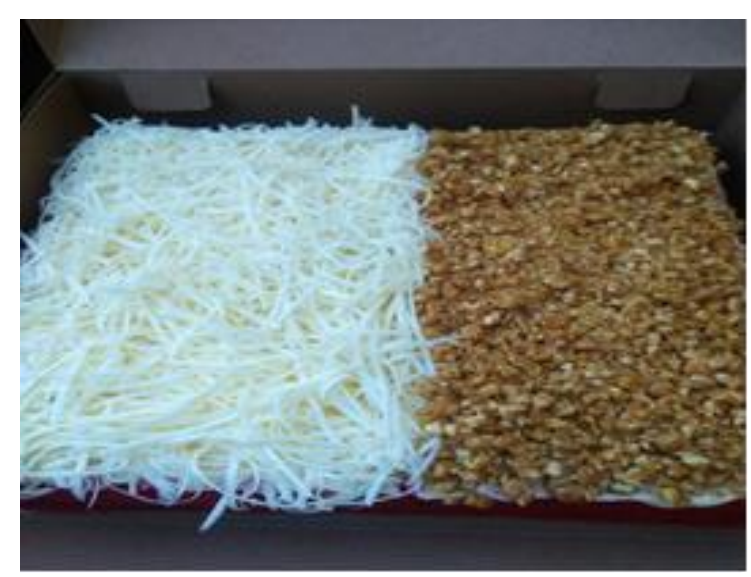

Gambar 5. Varian baru_cotton cake 


\section{c. Pelatihan Pengembangan Usaha.}

Kegiatan ini dilakukan dengan mengadakan sosialisasi kepada mitra pengabdian, materi yang dibahasa dalam sosialisasi ini adalah pengembangan usaha dari yuki brownies. karena pademi covid19, kegiatan sosialisasi ini dilakukan secara dari dengan menggunakan zoom, walaupun denikian tidak mengurangi niat dan kemauan dari semua pihak yang terlibat untukmenyelenggarakan sosialisasi dari ini. Adapun bentuk kegiatan terlihat pada gambar 6 berikut ini, pada kegiatan sosialisasi ini dilakukan dengan memanfaatkan media zoom, dimana pada sosialisasi daring ini dihadiri oleh semua pelaksana pengabdian dan mitra pengabdian adapun bukti screenshot pelatihan adalah sebagai berikut.

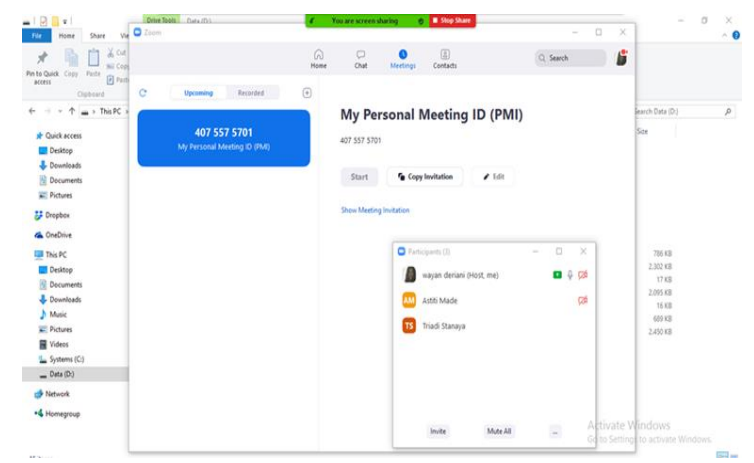

Gambar 6. Acara sosialisasi secara Daring

\section{Deferensiasi produk}

Diferensiasi Produk adalah penciptaan suatu produk atau citra produk yang cukup berbeda dengan produk-produk yang telah beredar dengan maksud untuk menarik konsumen (Griffin,2003:357). Diferensiasi Produk adalah kegiatan yang dilakukan oleh perusahaan dalam menghasilkan dan memasarkan produk yang berbeda dari tawaran pesaing. Perbedaan yang diciptakan mempunyai keunggulan nilai dan manfaat lebih untuk memenuhi kebutuhan pelanggan. [7]

Pada saat sosialisasi juga disampaikan materi tentang bagaimana cara menjalin kerjasama, materi ini diberikan karena mitra dalam berkeinginan untuk mengembangkan usahanya. Materi tentang bagaimana menjalin kerjasama dapat dilihat pada gambar 7 berikut ini.

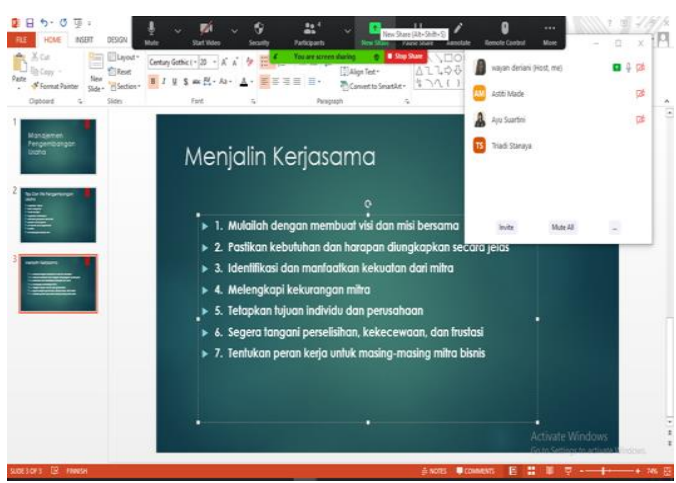

Gambar 7. Sosialisasi pengembangan Usaha

\section{d. Penyerahan Bantuan Alat}

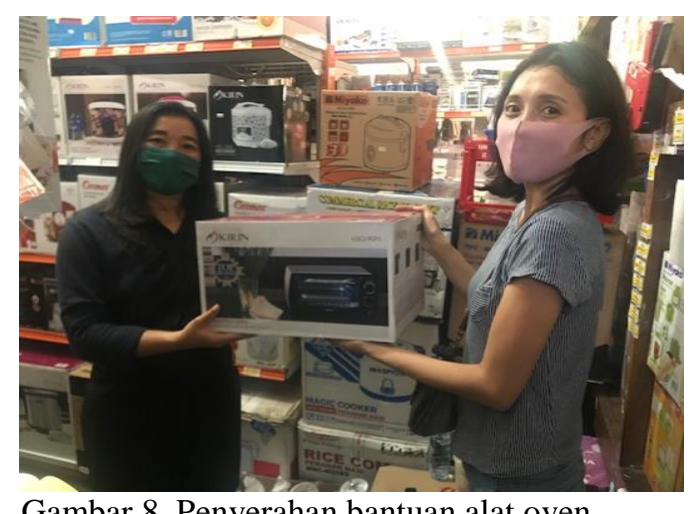

Gambar 8. Penyerahan bantuan alat oven

Guna menunjang kegiatan operasional mitra, untuk mengasilkan jumlah produk yang lebih banyak, maka diberikan bantuan 1 buah alat oven. Pada gambar 8 diatas didalam foto terlihat serah terima barang berupa satu buah oven/alat panggang yag diserahkan langsung oleh Ketua pelaksana dan diterima langsung oleh mitra pengabdian yaitu $\mathrm{Ibu} \mathrm{Ni}$ Komang Ayu Suartini.

\section{e. Evaluasi Kegiatan}

1. Dari informasi yang didapat berdasarkan hasil wawancara dengan mitra, bahwa selama pademi Covid-19 terjadi fluktuasi penjualan karena terpengaruh oleh pademi covid-19, dibulan januari penjualan mitra mencapai 2 juta rupiah, adapun data 
penjualan mitra dari bulan pebruari hingga mei 2020 terlihat pada tabel 2 sebagai derikut:

Tabel 2. Data Penjualan Peb-Mei 2020

\begin{tabular}{|l|l|l|l|}
\hline No & Penjualan per Bulan & Penjualan & $\begin{array}{c}\text { \% penjualan } \\
\text { dibandingkan } \\
\text { bulan } \\
\text { sebelumnya }\end{array}$ \\
\hline 1 & Pebruari 2020 & 1.200 .000 & Turun 800.000 \\
\hline 2 & Maret 2020 & 1.700 .000 & Naik 500.000 \\
\hline 3 & Apri1 2020 & 2.300 .000 & Naik 500.000 \\
\hline 4 & Mei 2020 & 4.000 .000 & Naik 1.700 .000 \\
\hline \multicolumn{2}{|c|}{ TOTAL } & Rp 9.200 .000 & \\
\hline
\end{tabular}

Jika ditampilkan dalam pie penjualan yuki brownies selama bulan Februari- Mei 2020 terlihat pada Gambar 9 sebagai berikut:

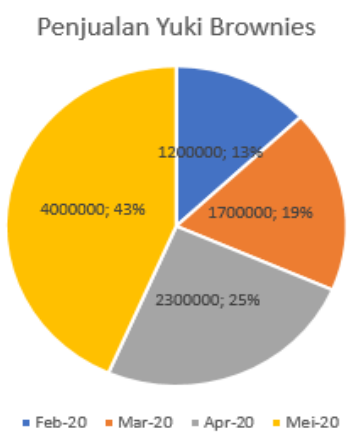

Gambar 9. Penjualan bulan Feb-Mei 2020

2. Terkait dengan perluasan pangsa pasar, saat ini memang belum signifikan, namun mitra menyampaikan bahwa mitra akan menjadin kerja sama dengan 2 orang calon mitra kerja, dimana saat ini sudah pada tahap testing produk supaya sesuai dengan persyaratan calon mitra. Ini membutikan bahwa sudah ada tindakan mitra untuk mengembangkan usahanya.

3. Hasil wawancara dengan mitra terkait hal ini, bahwa mitra melakukan perhitungan dari pelanggan-pelanggan 8 dari 12 atau $67 \%$ pelanggan menyukai desain kemasan yang dibuat produk yuki brownies. selain daripada itu juga dengan desain baru ini bisa mengurangi penggunaan plastik lebih dari $75 \%$.
4. Sejak berdirinya usaha yuki brownies ini, mitra hanya memiliki 1 (satu) Buah mesin panggang, sehingga terkendala dengan kuantitas produksi yang dihasilkan oleh yuki brownies. namun dengan bantuan 1 buah mesin panggang/oven bisa memenuhi jumlah pesanan hingga 100\%. Dapat disimpulkan bahwa jumlah produksi bisa meningkat $50 \%$.

\section{SIMPULAN}

Adapun kesimpulan dari kegiatan pengabdian masyarakat ini adalah sebagai berikut:

1. Telah dilaksanakan pembuatan desain kemasan, logo usaha dan branding dari yuki brownies.

2. Telah dihasilkan varian baru dari yuki brownies yaitu cotton cake dengan variant rasa red velvet.

3. Dari evaluasi yang dilakukan, efektivitas pelaksanaan pengabdian dapat dilihat dari data penjualan produk mitra yang diukur dari bulan pebruari-mei 2020 sebesar Rp 9.200.000 dimana dari penjualan tersebut terdiri $13 \%$ dibulan pebruari, $19 \%$ di bulan maret, $25 \%$ di bulan april dan $43 \%$ di bulan mei 2020.

4. Hasil wawancara dengan mitra terkait hal ini, bahwa mitra melakukan perhitungan dari pelanggan-pelanggan 8 dari 12 atau $67 \%$ pelanggan menyukai desain kemasan yang dibuat produk yuki brownies.

5. Dengan desain baru terutama untuk kemasan dan tas belanja mengurangi penggunaan plastik hingga $75 \%$, dan hal ini berdampak baik bagi lingkungan.

6. dengan bantuan 1 buah mesin panggang/oven bisa memenuhi jumlah pesanan hingga 100\%. Dapat disimpulkan bahwa jumlah produksi bisa meningkat $50 \%$. 


\section{UCAPAN TERIMA KASIH}

Puji dan syukur penulis panjatkan kepada Tuhan Yang Maha Esa, karena berkat rahmat dan karuni-nya penulis dapat menyelesaikan kegiatan dan pelaporan pengabdian masyarakat ini, untuk hal tersebut dalam kesempatan ini penulis ingin berterima kasih kepada:

1. Bapak Dr. Dadang Hermawan, Selaku Rektor ITB STIKOM Bali.

2. Bapak Ricky Aurelius Nurtanto Diaz, S.Kom.,MT, Selaku Ketua Program Studi Sistem Informasi.

3. Para reviewer yang senantiasa memberikan koreksi, masukan dalam penulisan laporan pengabdian ini.

4. Team pengabdian dan juga tentunya kepada mitra pengabdian yaitu mitra yuki brownies.

\section{DAFTAR PUSTAKA}

Muhamad Nastain (2017) "Branding dan Eksistensi Produk (Kajian Teoritik Konsep Branding dan Tantangan Eksistensi Produk)" Jurnal Program Studi Ilmu Komunikasi Universitas Ahmad Dahlan Yogyakarta Vol. 5, No. 1, hal. 14-26, ISSN: 23389176.

Honorata Ratnawati Dwi Putranti (2016) "Pengaruh kemasan ramah lingkungan dan informasi terhadap minat beli ulang (studi konsumen amdk kota semarang)" Prosiding Seminar Nasional INDOCOMPAC Universitas Bakrie, Jakarta.
I Ketut Surya Diarta, Putu Widhianti Lestari, dan Ida Ayu Putu Citra Dewi (2016) "Strategi Branding dalam Promosi Penjualan Produk Pertanian Olahan PT. Hatten Bali untuk Pasar Pariwisata Indonesia" Jurnal Manajemen Agribisnis, Vol. 4, No. 2, ISSN:2355-0759.

Deru R. Indika, dan Windy Utami Dewi (2018) "Analisis Rebranding untuk Membentuk Favorable Brand Image pada Radio Play99ers" Jurnal Bisnis, Manajemen dan Informatika (JBMI), Vol. 15, No. 2.

Ivo Ramadhani, Febri Yulika, dan Syafwandi (2018) "Re-Branding Identitas Logo Abidaufa" Jurnal Proporsi, Vol. 3, No. 2, ISSN: 2615-0247.

Aat Ruchiat Nugraha, S.Sos., M.Si. (2015) "Pengaruh design logo baru bumd yang berbasiskan kearifan lokal terhadap citra perusahaan (studi kuantitatif mengenai perubahan logo baru pada pdam kota bandung)" Jurnal Makna Vol. 5 No. 1

Thariz Baharmal Dejawata, Srikandi Kumadji, Yusri Abdillah" (2014) Pengaruh diferensiasi produk terhadap kepuasan pelanggan dan loyalitas pelanggan (survei pada pelanggan cake in jar cafe bunchbead kota malang) Jurnal Administrasi Bisnis (JAB)|Vol. 17 No. 2 